\title{
MIKROALBUMINURIA SEBAGAI PREDIKTOR LUARAN BURUK STROKE ISKEMIK AKUT DI RUMAH SAKIT UMUM PUSAT SANGLAH DENPASAR
}

\author{
MICROALBUMINURIA AS A POOR OUTCOME PREDICTOR AMONG ACUTE ISCHEMIC \\ STROKE PATIENTS IN SANGLAH HOSPITAL DENPASAR \\ Hesti Heptaningrum, * I Made Oka Adnyana, * Thomas Eko Purwata, *
}

\begin{abstract}
Introduction: Microalbuminuria is one of indicators for systemic endovascular damage related to endothelial damage and dysfunction. Microalbuminuria has become an important risk factor for predicting the risk and prognosis of cerebrovascular disease. However, its association with acute ischemic stroke remains unclear, particularly those related with other comorbidities.

Aim: To address the role of microalbuminuria as a predictor of poor neurological outcome among patients with acute ischemic stroke at Sanglah Hospital Denpasar.

Methods: This was a prospective cohort study involving acute ischemic stroke patients admitted at Sanglah Hospital Denpasar during October to December 2018. All patients who fulfilled inclusion and exclusion criteria and provided consent to participate in the study were included. Microalbuminuria was measured with albumin to creatinine ratio with concentration of 30-300mcg/mg. Stroke outcome was classified into either good or poor according to early and late National Institutes Health Stroke Scale (NIHSS) score (during patient's admission and $7^{\text {th }}$ day, respectively). Bivariate and multivariate statistical analyses were conducted.

Results: Sixty patients were recruited. Microalbuminuria increased poor neurological outcome among stroke patients significantly (RR 5.47; 95\% CI 2.17-13.8; $p<0.001)$. Multivariate analysis demonstrated that microalbuminuria $(R R=21.99 ; 95 \%$ CI 2.01-240.41; $p=0.011), D M(R R=11.66 ; 95 \%$ CI 2.00-67.65; $p=0.006)$, and dyslipidemia (RR 11.45; 95\% CI 1.10-119.23; $p=0.041)$ as an independent predictor of poor neurological outcome among acute ischemic stroke patients.
\end{abstract}

Discussion: Microalbuminuria is consistently independent predictors of poor outcome in admitted acute ischemic stroke patients.

Keywords: acute ischemic stroke, microalbuminuria, poor neurological outcome

\section{ABSTRAK}

Pendahuluan: Mikroalbuminuria merupakan salah satu indikator kerusakan endovaskular sistemik yang berkaitan dengan kerusakan endotel. Mikroalbuminuria menjadi salah satu faktor risiko penting terhadap prediktor risiko dan prognosis penyakit serebrovaskular. Meskipun demikian, hubungan antara mikroalbuminuria dan prognosis stroke iskemik akut masih belum jelas, terutama kaitannya dengan komorbiditas yang lain.

Tujuan: Membuktikan mikroalbuminuria sebagai prediktor luaran buruk penderita stroke iskemik akut di RSUP Sanglah Denpasar.

Metode: Penelitian ini merupakan kohort prospektif pada penderita stroke iskemik akut yang dirawat di RSUP Sanglah Denpasar mulai bulan Oktober hingga Desember 2018. Seluruh peserta yang memenuhi kriteria inklusi dan eksklusi dan bersedia berpartisipasi dalam penelitian ini diikutsertakan ke dalam studi. Mikroalbuminuria diukur dengan metode pengukuran rasio albumin kreatinin dengan kadar 30-300 mcg/mg. Luaran stroke dikelompokan menjadi baik dan buruk berdasar perbandingan nilai National Institutes Health Stroke Scale (NIHSS) awal saat pasien masuk dan hari ketujuh sejak awitan. Analisis statistik dilakukan secara bivariat dan multivariat.

Hasil: Enam puluh orang memenuhi kriteria eligibilitas. Mikroalbuminuria meningkatkan risiko luaran buruk pada pasien stroke secara bermakna (RR 5,47; IK 95\% 2,17 - 13,8; $\mathrm{p}=<0,001$ ). Analisis multivariat menunjukkan mikroalbuminuria ( $R R=21,99$; IK 95\% 2,01-240,41; $\mathrm{p}=0,011)$, DM ( $R R=11,66$; IK 95\% 2,00 - 67,65; $p=0,006)$, dan dislipidemia (RR 11,45; IK 95\% 1,10 - 119,23; p=0,041) sebagai prediktor independen luaran buruk selama perawatan pada penderita stroke iskemik akut.

Diskusi: Mikroalbuminuria konsisten merupakan prediktor independen luaran buruk selama perawatan pada penderita stroke iskemik akut.

Kata kunci: Luaran buruk, mikroalbuminuria, stroke iskemik akut.

*Departemen Ilmu Penyakit Saraf Fakultas Kedokteran Universitas Udayana/RSUP Sanglah Bali. Korespondensi: hesti46@yahoo.co.id 


\section{PENDAHULUAN}

Mikroalbuminuria merupakan penanda disfungsi endotel. Proteinuria dan albuminuria berhubungan dengan peningkatan sitokin inflamasi dan stres oksidatif, sehingga berpotensi menyebabkan kerusakan pembuluh darah yang berlebihan saat onset stroke. ${ }^{1,2}$ Individu dengan mikroalbuminuria memiliki prevalensi yang lebih tinggi terjadinya infark lakunar dan tunika intima yang tebal. ${ }^{3}$ Pada penelitian yang dilakukan sebelumnya dikatakan bahwa terdapat peningkatan insiden mikroalbuminuria pada stroke iskemik akut dan mikroalbuminuria berhubungan dengan tingkat keparahan stroke iskemik akut. ${ }^{4}$ Penelitian European Prospective Investigation pada populasi di Norfolk, mikroalbuminuria secara independen terkait dengan 50\% peningkatan risiko stroke. Suatu penelitian kohort di Jepang yang meneliti faktor risiko stroke menunjukkan bahwa albumin urin merupakan faktor risiko independen untuk stroke pada pria tapi tidak pada wanita. Hubungan antara mikroalbuminuria dan stroke berulang juga telah dilaporkan. Mikroalbuminuria secara independen memprediksi terjadinya stroke pada populasi orang tua di Amerika (rerata usia 65 tahun) dengan stroke iskemik sebelumnya atau transient ischemic attack (TIA). Pada penelitian lain dilaporkan bahwa mikroalbuminuria berkorelasi dengan klinis serebrovaskular seperti serebral iskemik lakunar, stenosis arteri serebri media, gangguan aliran darah arteri karotis dan reaktivitas vasomotor pada ultrasonografi doppler, dan peningkatan ketebalan tunika intima media arteri karotis. Selain itu, pasien stroke akut dengan mikroalbuminuria memiliki hasil yang lebih buruk daripada mereka yang tidak memiliki mikroalbuminuria. ${ }^{5}$

Berdasarkan uraian tersebut maka diusulkan penelitian kadar mikroalbuminuria sebagai prediktor luaran buruk pada penderita stroke iskemik akut di Rumah Sakit Umum Pusat (RSUP) Sanglah Denpasar.

\section{TUJUAN}

Membuktikan mikroalbuminuria sebagai prediktor luaran buruk penderita stroke iskemik akut di RSUP Sanglah Denpasar.

\section{METODE}

Rancangan penelitian yang digunakan adalah observasional analitik kohort prospektif dengan melihat dua kelompok subjek yang memiliki mikroalbuminuria dan yang tidak. Penelitian dilakukan di Bagian Neurologi FK UNUD/RSUP Sanglah Denpasar mulai Oktober hingga Desember 2018. Pemeriksaan skor National Institutes Health Stroke Scale (NIHSS) dilakukan di instalasi gawat darurat dan bangsal perawatan pasien. Pemeriksaan laboratorium dan pencitraan dilakukan di Instalasi Laboratorium Prodia dan Radiologi RSUP Sanglah Denpasar. Populasi target adalah semua penderita stroke iskemik akut. Populasi terjangkau adalah penderita stroke iskemik akut yang menjalani perawatan di Bagian Neurologi FK UNUD/RSUP Sanglah Denpasar. Kriteria inklusi pada penelitian ini meliputi pasien stroke iskemik akut awitan $\leq 72$ jam, usia 40-65 tahun, skor glasgow coma scale (GCS) 15, pasien atau keluarga menyetujui untuk berpartisipasi dalam penelitian serta menandatangani formulir persetujuan. Adapun kriteria eksklusi pada penelitian ini antara lain meliputi penderita stroke iskemik yang tidak dikonfirmasi dengan CT scan kepala, penderita stroke iskemik dengan riwayat stroke sebelumnya dari anamnesis ataupun data penunjang, penderita stroke iskemik yang mengalami gangguan fungsi organ lain seperti paru, hati, atau ginjal, penderita stroke dengan penyakit infeksi akut, keganasan, penyakit autoimun, dan riwayat stroke sebelumnya, penderita stroke tipe perdarahan, termasuk perdarahan intraserebral, perdarahan subaraknoid, dan perdarahan intraventrikuler.

Mikroalbuminuria didefinisikan sebagai rasio albumin urin dan kreatinin 30-300 mcg/mg pada sampel urin pertama di pagi hari. ${ }^{4}$ Pemeriksaan ini dilakukan dengan sampel urin sewaktu, ditampung di kontainer urin, dengan metode pengukuran rasio albumin kreatinin yang dikerjakan di Laboratorium Prodia Denpasar. Kriteria mikroalbuminuria bila ditemukan dalam jumlah $30-300 \mathrm{mcg} / \mathrm{mg}$ kreatinin. Data berskala nominal dikotomi. Luaran perawatan stroke adalah kondisi saat perawatan setelah awitan hari ketujuh yang dapat menunjukkan hasil setelah 
perawatan. Luaran dinilai dengan menggunakan skor NIHSS yang telah tervalidasi. Penghitungan NIHSS sebanyak dua kali. Pertama saat penderita masuk di instalasi gawat darurat dan yang kedua pada hari ketujuh sejak awitan, kemudian dilakukan perbandingan antara nilai yang pertama dan kedua. Hasil akhir akan dikelompokkan menjadi luaran perawatan buruk jika didapatkan peningkatan nilai NIHSS antara awal dan akhir sebesar lebih dari atau sama dengan dua poin atau didapatkan kematian selama perawatan. Luaran perawatan baik jika di dapatkan peningkatan nilai NIHSS antara awal dan akhir sebesar kurang dari dua poin, nilai NIHSS awal dan akhir sama, atau penurunan nilai NIHSS. ${ }^{6}$

Stroke iskemik didefinisikan sebagai episode disfungsi neurologis yang disebabkan oleh infark pada otak, medula spinalis, dan retina, berdasarkan pada bukti patologis, pencitraan, atau gejala klinis yang menetap lebih dari 24 jam atau diakhiri dengan kematian, tanpa penyebab selain vaskular. ${ }^{7}$ Diagnosis stroke ditegakkan sesuai pemeriksaan klinis neurologis yang ditemukan dan dikonfirmasi dengan menggunakan CT scan kepala tanpa kontras dan tidak ditemukannya gambaran hiperdense pada CT scan kepala tanpa kontras.

Penelitian ini dilakukan dalam tiga tahap. Tahap pertama melakukan pengambilan sumber data sesuai dengan metode pengambilan data yang digunakan dan dilakukan penyaringan sumber data menurut kriteria inklusi dan eksklusi yang telah disepakati, serta bersedia menandatangani surat persetujuan informed consent. Penderita tetap mendapatkan pelayanan secara maksimal sesuai penyakit yang dideritanya. Tahap kedua melakukan pencatatan identitas subjek, pemeriksaan keadaan vital, anamnesis, pemeriksaan fisik secara umum, pemeriksaan klinis neurologis, pemeriksaan penunjang seperti laboratorium dan pencitraan sesuai indikasi, penilaian derajat keparahan stroke saat itu juga dengan menggunakan sistem skoring NIHSS saat awal dan saat lewat dari fase akut. Tahap ketiga melakukan penataan data dalam bentuk tabel dan selanjutnya dilakukan analisis data. Data hasil penelitian akan dianalisis secara statistik dengan bantuan program SPSS for Windows versi 20.0. Analisis data dilakukan dalam dua tahapan yaitu tahapan statistik deskriptif digunakan untuk melihat gambaran karakteristik dasar subjek penelitian, dan tahapan statistik analitik yang dilakukan dua tahap, yaitu uji hipotesis untuk analisis bivariat dengan variabel bebas dan variabel tergantung yang berskala nominal dikotomi menggunakan metode Chi-square dengan continuity correction. Jika syarat uji Chisquare tidak terpenuhi, metode yang digunakan adalah uji Fisher. Tingkat kemaknaan dinyatakan dengan $\mathrm{p}$ dan risiko relatif (RR) dengan interval kepercayaan 95\%. Untuk mengetahui pengaruh faktor-faktor lain sebagai prediktor luaran perawatan penderita stroke iskemik akut dilakukan analisis multivariat menggunakan metode regresi logistik. Penelitian telah mendapatkan persetujuan kelayakan etik dari Komite Etik Penelitian Fakultas Kedokteran Universitas Udayana/RSUP Sanglah dengan nomor 604/UN.14.2.2.V.12/PD/2018.

\section{HASIL}

Penelitian melibatkan 60 subjek dengan karakteristik dasar subjek yang tercantum pada Tabel 1. Data usia sampel pada penelitian ini tidak terdistribusi normal $(p<0,001)$ sehingga disajikan dalam bentuk median dengan jangkauan interkuartil (interquartile range), yakni $60,5 \pm 11$ tahun. Jenis kelamin laki-laki mendominasi sampel penelitian dengan jumlah sebesar 36 orang(60\%), sedangkan sisanya adalah perempuan dengan total jumlah sebesar 24 orang $(40 \%)$. Kadar mikroalbumin dalam urin pada 60 subjek tidak terdistribusi normal $(\mathrm{p}<0,001)$ sehingga disajikan dalam bentuk median dan jangkauan interkuartil, yakni sebesar 28,65 \pm $55,96 \mathrm{mg} / \mathrm{dL}$. Apabila diklasifikasikan lebih lanjut berdasarkan kriteria mikroalbuminuria, sebanyak $31(51,7 \%)$ orang memiliki kadar albumin urin normal, sedangkan $29(48,3 \%)$ orang menderita mikroalbuminuria. Sementara itu terdapat lima faktor komorbiditas lainnya yang diteliti dalam studi ini, meliputi riwayat hipertensi, diabetes melitus, dan dislipidemia, serta riwayat merokok dan mengkonsumsi minuman beralkohol. Mayoritas subjek pada penelitian ini menderita hipertensi 
Tabel 1. Karakteristik Dasar Subjek Penelitian $(n=60)$

\begin{tabular}{|c|c|}
\hline Variabel & n $(\%)$ \\
\hline Usia (tahun), Median (Min-maks) & $60,5(1-11)$ \\
\hline \multicolumn{2}{|l|}{ Jenis Kelamin } \\
\hline - Laki-laki & $36(60)$ \\
\hline - Perempuan & $24(40)$ \\
\hline $\begin{array}{l}\text { Mikroalbuminuria ( } \mu \mathrm{g} / \mathrm{mg} \text { ), } \\
\text { Median (Min-maks) }\end{array}$ & $\begin{array}{c}28,65 \\
(1-55,96)\end{array}$ \\
\hline - Mikroalbuminuria positif & $29(48,3)$ \\
\hline - Mikroalbuminuria negatif & $31(51,7)$ \\
\hline \multicolumn{2}{|l|}{ Riwayat Hipertensi } \\
\hline - Ya & $42(70)$ \\
\hline - Tidak & $18(30)$ \\
\hline \multicolumn{2}{|l|}{ Riwayat Diabetes Melitus } \\
\hline - Ya & $34(56,7)$ \\
\hline - Tidak & $26(43,3)$ \\
\hline \multicolumn{2}{|l|}{ Riwayat Dislipidemia } \\
\hline - Ya & $25(41,7)$ \\
\hline - Tidak & $35(58,3)$ \\
\hline \multicolumn{2}{|l|}{ Riwayat Merokok } \\
\hline - Ya & $29(48,7)$ \\
\hline - Tidak & $31(51,3)$ \\
\hline \multicolumn{2}{|l|}{ Riwayat Konsumsi Alkohol } \\
\hline - Ya & $9(15)$ \\
\hline - Tidak & $51(85)$ \\
\hline \multicolumn{2}{|l|}{ Luaran } \\
\hline - Luaran baik & $28(46,7)$ \\
\hline - Luaran buruk & $32(53,3)$ \\
\hline
\end{tabular}

(42 orang; 70\%), DM didapatkan pada 34 orang $(56,7 \%)$, dan dislipidemia didapatkan pada 25 orang $(41,7 \%)$. Lebih lanjut, sebanyak $29(48,7 \%)$ orang merupakan perokok aktif dan hanya $9(15 \%)$ orang yang mengonsumsi minuman beralkohol. Lebih dari separuh subjek mengalami luaran buruk (32 orang;
$53,3 \%)$.

Berdasarkan Tabel 2, tidak terdapat perbedaan proprosi jenis kelamin laki-laki antara kelompok dengan dan tanpa mikroalbuminuria. Sementara itu, proporsi perempuan yang menderita mikroalbuminuria lebih sedikit dibandingkan dengan yang tidak $(11[45,8 \%]$ vs. $13[54,2 \%])$. Data usia tidak terdistribusi normal sehingga disajikan dalam bentuk median dan jangkauan. Usia pada kelompok pasien dengan mikroalbuminuria memiliki median dan jangkauan minimum-maksimum sebesar 64 (5066) tahun dan pada kelompok tanpa mikroalbuminuria adalah sebesar 58 (37-66) tahun. Lebih lanjut, awitan stroke didapatkan tidak terdistribusi normal.

Hubungan antara mikroalbuminuria sebagai variabel bebas dengan luaran perawatan penderita stroke iskemik akut sebagai variabel tergantung dinilai dengan menggunakan analisis bivariat. Uji hipotesis yang digunakan adalah metode Chi-square sehingga diperoleh nilai risiko relatif(RR) dengan IK 95\%. Tingkat kemaknaan penelitian ini ditetapkan dengan nilai probabilitas $p<0,05$. Hasil analisis disajikan pada Tabel 2.

Berdasarkan Tabel 2, jumlah penderita stroke iskemik akut yang memiliki luaran buruk didapatkan lebih tinggi pada kelompok dengan mikroalbuminuria, yakni sebesar 25 orang, dibandingkan dengan kelompok dengan kadar albumin urin normal (7 orang). Sebaliknya, penderita stroke iskemik akut yang memiliki luaran baik didapatkan lebih banyak jumlahnya pada kelompok dengan kadar albumin urin normal (24 orang) dibandingkan dengan kelompok dengan mikroalbuminuria (4 orang). Hasil analisis bivariat menunjukkan penderita stroke iskemik

Tabel 2. Analisis Bivariat Mikroalbuminuria, serta Mikroalbuminuria dengan DM Dan Hipertensi dengan Luaran Perawatan Pasien Stroke Iskemik Akut (n=60)

\begin{tabular}{|c|c|c|c|c|}
\hline Variabel & $\begin{array}{c}\text { Luaran Buruk } \\
(\mathrm{n}=32) \\
\mathrm{n}(\%)\end{array}$ & $\begin{array}{c}\text { Luaran Baik } \\
(\mathrm{n}=\mathbf{2 8 )} \\
\mathrm{n}(\%)\end{array}$ & $\begin{array}{c}\text { RR } \\
(\text { IK 95\%) }\end{array}$ & $\mathbf{p}$ \\
\hline \multicolumn{5}{|l|}{ Mikroalbuminuria dan Normal } \\
\hline - Mikroalbuminuria & $25(86,2)$ & $4(13,8)$ & \multirow{2}{*}{$\begin{array}{c}5,47 \\
(2,17-13,8)\end{array}$} & \multirow[t]{2}{*}{$0,001 *$} \\
\hline - Normal & $7(22,6)$ & $24(77,4)$ & & \\
\hline \multicolumn{5}{|c|}{ Mikroalbuminuria dengan/tanpa DM dan Hipertensi } \\
\hline - Mikroalbuminuria dengan DM dan hipertensi & $23(92)$ & $2(8)$ & \multirow{2}{*}{$\begin{array}{c}1,84 \\
(0,69-4,94)\end{array}$} & \multirow[t]{2}{*}{$0,08 \dagger$} \\
\hline - Mikroalbuminuria tanpa DM dan hipertensi & $2(50)$ & $2(50)$ & & \\
\hline
\end{tabular}

*Uji Chi-square; †Uji Fisher; RR; risiko relatif; IK; interval kepercayaan; DM: diabetes melitus. 
Tabel 3. Analisis Bivariat terhadap Faktor-faktor Lain yang Memengaruhi Luaran Perawatan Penderita Stroke Iskemik Akut (n=60)

\begin{tabular}{|c|c|c|c|c|}
\hline Variabel & $\begin{array}{c}\text { Luaran Buruk } \\
(\mathbf{n}=\mathbf{3 2}) \\
\text { n }(\%)\end{array}$ & $\begin{array}{c}\text { Luaran Baik } \\
\qquad(\mathbf{n}=\mathbf{2 8}) \\
\text { n }(\%)\end{array}$ & $\begin{array}{c}\text { RR } \\
(\text { IK 95\%) }\end{array}$ & $\mathbf{p}$ \\
\hline \multicolumn{5}{|l|}{ Jenis Kelamin } \\
\hline - Laki-laki & $19(52,8)$ & $17(47,2)$ & $0,97(0,60-1,58)$ & $0,916^{*}$ \\
\hline - Perempuan & $13(54,2)$ & $11(45,8)$ & & \\
\hline \multicolumn{5}{|l|}{ Riwayat Hipertensi } \\
\hline - Ya & $26(61,9)$ & $16(38,1)$ & $1,86(0,93-3,72)$ & $0,08^{*}$ \\
\hline - Tidak & $6(33,3)$ & $12(66,7)$ & & \\
\hline \multicolumn{5}{|l|}{ Riwayat Diabetes Melitus } \\
\hline - Ya & $29(85,3)$ & $5(14,7)$ & $7,39(2,53-21,63)$ & $0,001 \dagger$ \\
\hline - Tidak & $3(11,5)$ & $23(88,5)$ & & \\
\hline \multicolumn{5}{|l|}{ Riwayat Dislipidemia } \\
\hline - Ya & $18(72)$ & $7(28 \%)$ & $1,80(1,12-2,89)$ & $0,014^{*}$ \\
\hline - Tidak & $14(40)$ & $21(60 \%)$ & & \\
\hline \multicolumn{5}{|l|}{ Riwayat Merokok } \\
\hline - Ya & $21(72,4)$ & $8(27,6)$ & $2,04(1,21-3,45)$ & $0,04 *$ \\
\hline - Tidak & $11(35,5)$ & $20(64,5)$ & & \\
\hline \multicolumn{5}{|l|}{ Riwayat Konsumsi Alkohol } \\
\hline - Ya & $7(77,8)$ & $2(22,2)$ & $1,59(1,01-2,48)$ & $0,155 \dagger$ \\
\hline - Tidak & $25(49)$ & $26(51)$ & & \\
\hline
\end{tabular}

*Uji Chi-square; †Uji Fisher; RR;risiko relatif; IK;interval kepercayaan; DM:diabetes melitus.

akut dengan mikroalbuminuria secara signifikan meningkatkan risiko 5,4 kali untuk mengalami luaran buruk dibandingkan dengan penderita stroke iskemik akut dengan kadar albumin urin normal $(\mathrm{RR}=5,4$; IK 95\% 2,17 - 13,8; $\mathrm{p}=0,001)$. Berdasarkan Tabel 2, dilakukan perbandingan pasien dengan mikroalbuminuria pada pasien dengan DM dan hipertensi dan pasien dengan mikroalbuminuria tanpa DM dan hipertensi. Hasilnya, didapatkan peningkatan risiko luaran buruk sebesar 1,84 kali lebih tinggi pada penderita mikroalbuminuria dengan DM dan hipertensi dibandingkan dengan mikroalbuminuria tanpa DM dan hipertensi (RR=1,84; IK95\% 0,694,94; $\mathrm{p}=0,08$ ).

Hasil analisis bivariat faktor-faktor lain yang berpengaruh terhadap luaran perawatan penderita stroke iskemik akut disajikan pada Tabel 3. Varibel yang signifikan dilanjutkan dengan analisis multivariat, yakni pada analisis bivariat didapatkan dengan nilai $\mathrm{p}<0,25$. Variabel tersebut adalah mikroalbuminuria, riwayat hipertensi, DM, dislipidemia, dan merokok. Hasil analisis multivariat selengkapnya ditampilkan pada Tabel 4.

Berdasarkan hasil analisis multivariat, didapatkan bahwa faktor risiko independen terhadap luaran perawatan penderita stroke iskemik akut adalah mikroalbuminuria, riwayat hipertensi, DM, dislipidemia, merokok, dan riwayat mengonsumsi alkohol. Pasien dengan mikroalbuminuria memiliki risiko lebih dari 21 kali lebih tinggi mengalami luaran perawatan stroke yang buruk dibandingkan dengan kelompok pasien tanpa mikroalbuminuria $(\mathrm{RR}=21,99$; IK95\% 2,01-240,41; $\mathrm{p}=0,011)$ dengan hasil yang bermakna secara statistik. Lebih lanjut, pasien dengan DM juga berisiko 11 kali lebih tinggi mengalami luaran perawatan stroke yang buruk dibandingkan dengan penderita stroke tanpa DM ( $R R=11,66$; IK95\% 2,00-67,65; p=0,006). Selain itu, pasien dengan dislipidemia juga 11 kali lebih berisiko mengalami luaran buruk dibandingkan dengan penderita tanpa dislipidemia $(\mathrm{RR}=11,45$; IK95\% 1,10-119,23; $\mathrm{p}=0,041$ ). 
Tabel 4. Analisis Multivariat Regresi Logistik $(n=60)$

\begin{tabular}{|c|c|c|c|c|}
\hline & Variabel & Koefisien & $\begin{array}{c}\text { RR } \\
(\text { IK 95\%) }\end{array}$ & $\mathbf{p}^{*}$ \\
\hline \multirow{6}{*}{ Langkah 1} & Mikroalbuminuria & 3,39 & $29,72(1,54-572,25)$ & 0,025 \\
\hline & Riwayat Hipertensi & 0,43 & $1,53(0,23-10,35)$ & 0,661 \\
\hline & $\mathrm{DM}$ & 2,09 & $8,10(1,08-61,04)$ & 0,042 \\
\hline & Dislipidemia & 2,56 & $12,92(0,93-179,66)$ & 0,057 \\
\hline & Riwayat Merokok & 0,16 & $1,17(0,20-6,97)$ & 0,86 \\
\hline & Riwayat Konsumsi Alkohol & 0,66 & $1,93(0,98-38,37)$ & 0,67 \\
\hline \multirow{5}{*}{ Langkah 2} & Mikroalbuminuria & 3,47 & $32,14(1,85-558,65)$ & 0,017 \\
\hline & Riwayat Hipertensi & 0.43 & $1,54(0,23-10,30)$ & 0,66 \\
\hline & $\mathrm{DM}$ & 2,11 & $8,22(1,10-61,67)$ & 0,04 \\
\hline & Dislipidemia & 2,62 & $13,80(1,07-177,18)$ & 0,044 \\
\hline & Riwayat Konsumsi Alkohol & 0,69 & $2,0(0,10-38,32)$ & 0,647 \\
\hline \multirow{4}{*}{$\begin{array}{l}\text { Langkah } 3 \\
\text { LA }\end{array}$} & Mikroalbuminuria & 3,50 & $33,19(1,90-578,36)$ & 0,016 \\
\hline & $\mathrm{DM}$ & 2,14 & $8,49(1,14-63,58)$ & 0,037 \\
\hline & Dislipidemia & 2,63 & $13,88(1,08-178,80)$ & 0,044 \\
\hline & Riwayat Konsumsi Alkohol & 0,84 & $2,32(0,13-41,94)$ & 0,57 \\
\hline \multirow[t]{3}{*}{ Langkah 4} & Mikroalbuminuria & 3,09 & $21,99(2,01-240,41)$ & 0,011 \\
\hline & $\mathrm{DM}$ & 2,46 & $11,66(2,00-67,65)$ & 0,006 \\
\hline & Dislipidemia & 2,44 & $11,45(1,10-119,23)$ & 0,041 \\
\hline
\end{tabular}

*Uji Chi-square; RR; risiko relatif; IK; interval kepercayaan; DM:diabetes melitus

\section{PEMBAHASAN}

Berdasarkan kadar mikroalbuminuria, didapatkan 29 orang dengan mikroalbuminuria positif dan 31 orang tanpa mikroalbuminuria. Jenis kelamin laki-laki masing-masing didapatkan 18 orang pada kelompok mikroalbuminuria positif dan negatif. Jenis kelamin perempuan didapatkan pada 11 orang pada kelompok mikroalbuminuria positif dan 13 orang pada kelompok mikroalbuminuria negatif. Hal ini sesuai dengan penelitian Thampy dan Pais yang juga mendapatkan bahwa proporsi mikroalbuminuriaa positif lebih tinggi pada jenis kelamin laki-laki dibandingkan perempuan. ${ }^{8}$ Pasien stroke yang menderita mikroalbuminuria cenderung berusia lebih tua dibandingkan dengan pasien tanpa mikroalbuminuria (median [min-maks]: 64 [5065] vs 58 [37-66] tahun). Hal ini sesuai dengan temuan Gumbinger yang mendapatkan rerata usia pasien lebih tua pada penderita mikroalbuminuria dibandingkan dengan pasien tanpa mikroalbuminuria (rerata \pm SD: $72,4 \pm 10,4$ vs $66,1 \pm 11,1$ tahun). ${ }^{9}$ Hal ini kemungkinan berhubungan dengan penurunan angka kelangsungan hidup pasien usia tua dan penurunan kemampuan filtrasi glomerulus seiring pertambahan usia. Berdasarkan luaran perawatan, didapatkan 32 orang dengan luaran buruk dan 28 orang dengan luaran baik. Penelitian Cha yang meneliti 2.772 penderita stroke iskemik akut menemukan bahwa usia lebih tua meningkatkan risiko luaran buruk stroke. ${ }^{10}$ Hal ini sesuai dengan data pada studi ini. Apabila dianalisis lebih lanjut, kelompok dengan luaran buruk stroke cenderung memiliki usia yang lebih tua dibandingkan dengan yang memiliki luaran baik. Jenis kelamin pada kedua kelompok didapatkan lebih banyak laki-laki, yaitu 19 orang pada kelompok luaran buruk dan 17 orang pada kelompok luaran baik.

Median usia didapatkan lebih tinggi pada kelompok luaran buruk yaitu 64 (min-maks: 50-66) tahun dibandingkan kelompok luaran baik sebesar 58 (37-66) tahun. Hal ini mungkin terkait dengan sering terdapatnya lebih dari satu faktor risiko pada 
usia tua yang dapat mengganggu struktur dinding pembuluh darah seperti hipertensi, diabetes melitus, hiperkolesterolemia, dan komponen metabolik lain seperti homosistein, sehingga didapatkan aterotrombosis, degenerasi lipohialin, dan stenosis lumen. ${ }^{11}$ Hal lain yang diduga terjadi pada usia tua adalah berkurangnya jumlah sel neuron dan jumlah sinaps antar neuron.

Penderita stroke iskemik akut yang memiliki luaran buruk didapatkan lebih banyak pada kelompok mikroalbuminuriapositif. Sebaliknya, penderitastroke iskemik akut yang memiliki luaran baik didapatkan lebih banyak pada kelompok mikroalbuminuria negatif. Penelitian Gumbinger menunjukkan bahwa pasien dengan stroke iskemik yang memiliki mikroalbuminuria memiliki risiko lima kali lebih tinggi mengalami luaran buruk dibandingkan dengan kelompok tanpa mikroalbuminuria $(\mathrm{RO}=5,07$; IK95\% 2,18-11,77; $\mathrm{p}=0,004) .{ }^{12}$ Pada studi Thampy dan Pais, mikroalbuminuria meningkatkan risiko perburukan klinis dini pada pasien dengan stroke iskemik $(\mathrm{RO}=15,69$; IK95\% 1,08-227,88; $\mathrm{p}=0,044) .{ }^{8}$ Hal ini sesuai dengan temuan yang didapatkan pada studi ini bahwa mikroalbuminuria meningkatkan risiko luaran buruk penderita stroke.

Pada studi ini, analisis statistik menggunakan uji Chi-square mendapatkan bahwa mikroalbuminuria secara signifikan meningkatkan risiko terjadinya luaran buruk pada penderita stroke sebesar lima kali $(\mathrm{RR}=5,47$; IK95\% 2,17-13,8; $<00,001)$. Hal ini berarti penderita stroke iskemik dengan mikroalbuminuria positif $\quad(\geq 30 \mu \mathrm{g} / \mathrm{mg} \quad$ kreatinin $) \quad$ mempunyai kemungkinan 5,4 kali lebih besar untuk mengalami luaran buruk dibandingkan mikroalbuminuria negatif $(<30 \mu \mathrm{g} / \mathrm{mg}$ kreatinin). Jika penelitian ini diulang dengan menggunakan cara dan metode yang sama, maka kelompok mikroalbuminuria positif dapat berisiko mengalami luaran buruk sebesar 2,17 sampai 13,8 kali lebih besar dibandingkan kelompok mikroalbuminuria negatif. Zakria berpendapat bahwa mikroalbuminuria dapat menggambarkan disfungsi endotel secara umum sehingga meningkatkan penetrasi aterogenik lipoprotein pada dinding pembuluh darah. Paparan endotelium terhadap faktor risiko menyebabkan disfungsi endotel dengan penurunan bioavailabilitas NO, peningkatan oksidan, dan ekspresi adhesi molekul. ${ }^{13}$ Hal ini diikuti oleh penebalan lapisan intima, stenosis arteri, terjadi ruptur plak dan terbentuklah trombosis endovaskular. ${ }^{4,14}$ Vasokontriksi yang terjadi akibat disfungsi endotel tersebut menyebabkan peningkatan tekanan arterial, glomerulus dan permeabilitas arteri. Hal ini memicu membran basal glomerulus kehilangan muatan negatif normal dan hilangnya heparan sulfat dari matriks ekstraselular dan membran plasma dapat menyebabkan peningkatan permeabilitas pada membran vaskular dan dapat meningkatkan pengumpulan partikel aterogenik di dinding arteri. ${ }^{4}$

Mikroalbuminuria disebabkan dari kebocoran yang berhubungan dengan gangguan endotel glomerolus yang terkait dengan penyakit vaskular sistemik melalui stres oksidatif, peningkatan permeabilitas, dan kekakuan pembuluh darah arteri. ${ }^{15}$ Penderita stroke iskemik akut yang memiliki luaran buruk didapatkan lebih tinggi pada kelompok DM yaitu 29 orang $(85,3 \%)$ dibandingkan kelompok tanpa DM yaitu 3 orang $(11,5 \%)$. Penelitian ini menunjukkan bahwa DM meningkatkan risiko luaran buruk perawatan penderita stroke iskemik akut sebesar 7,39 kali lebih tinggi dibandingkan dengan kelompok tanpa DM (RR=7,39; IK95\% 2,53-21,63; $\mathrm{p}=0,001)$.

Hasil penelitian ini sesuai dengan penelitian $\mathrm{Lau}^{16}$ yang menemukan bahwa diabetes melitus meningkatkan risiko terjadinya luaran buruk pada penderita stroke. Chen berpendapat bahwa luaran buruk pada stroke iskemik meningkat akibat pengaruh hiperglikemia dan hiperinsulinemia terhadap reperfusi. ${ }^{17}$ Sebagaimana diketahui, keadaan hiperglikemia dan hiperinsulinemia terbukti dapat meningkatkan kadar penghambat aktivator plasminogen jaringan tipe 1 (tissue plasminogen activator inhibitor type 1) dan menurunkan aktivitas aktivator plasminogen jaringan dalam keadaan bebas (free tissue plasminogen activator) sehingga berperan dalam menunda reperfusi pada penumbra iskemik dan menurunkan kemampuan rekanalisasi pasca terapi rtPA. Selain itu, hiperglikemia juga berperan dalam meningkatkan aktivasi dan agregasi platelet ke sel endotel, sehingga memperberat kondisi iskemia akibat oklusi. 
Penderita stroke iskemik akut yang memiliki luaran buruk didapatkan lebih tinggi pada kelompok dislipidemia yaitu 18 orang (72\%) dibandingkan kelompok tanpa dislipidemia yaitu 14 orang (40\%). Hasil pada penelitian ini serupa dengan studi $\mathrm{Xu}$ yang menunjukkan bahwa penderita stroke dengan dislipidemia (hipertrigliseridemia, kadar kolesterol LDL tinggi, dan HDL rendah) meningkatkan risiko luaran perawatan buruk stroke. Pada studi tersebut, hipertrigliseridemia, kadar LDL tinggi, dan HDL rendah masing-masing meningkatkan risiko luaran buruk stroke sebesar 3,013 (IK95\% 1,2597,214); 3,157 (IK95\% 1,306-7,631), dan 0,482 (IK95\% 0,282-0,921). ${ }^{18}$ Sebagaimana diketahui bahwa HDL merupakan suatu antioksidan, yang memegang peranan penting dalam patogenesis terjadinya stroke iskemik melalui inhibisi oksidasi fosfolipid dan aktivitas LDL. Begitu pula kolesterol LDL yang menginisiasi timbulnya inflamasi dan membentuk plak pada dinding pembuluh darah sehingga menghambat aliran darah. Kolesterol LDL merupakan faktor reaksi oksidasi lebih kuat daripada total kolesterol dan kolesterol HDL. Dalam hal ini, luaran buruk stroke didefinisikan sebagai skor NIHSS $>10$ atau kematian pada saat akhir studi. Studi lain juga menunjukkanpeningkatan kadar small dense LDL (sdLDL) memiliki berhubungan dengan prognosis yang lebih buruk pada penderita stroke. ${ }^{19}$

Penderita stroke iskemik akut yang memiliki luaran buruk didapatkan lebih tinggi pada kelompok perokok yaitu 21 orang $(72,4 \%)$ dibandingkan kelompok tidak merokok yaitu 11 orang $(35,5 \%)$. Sebuah meta analisis yang melibatkan 303.134 subjek menemukan bahwa merokok meningkatkan risiko stroke iskemik secara bermakna $(\mathrm{RO}=1,61$; IK95\% 1,34-1,93; p<0,001). ${ }^{20}$

Berdasarkan hasil analisis multivariat, didapatkan mikroalbuminuria positif, riwayat hipertensi, diabetes melitus, riwayat dislipidemia, riwayat merokok dan riwayat konsumsi alkohol merupakan faktor risiko independen terhadap luaran perawatan penderita stroke iskemik akut. Penderita stroke iskemik akut dengan mikroalbuminuria positif memiliki risiko 21,99 kali lebih besar untuk mengalami luaran buruk selama perawatan dibandingkan penderita stroke iskemik akut dengan mikroalbuminuria negatif $(\mathrm{RR}=21,99$; IK95\% 2,01240,41; $\mathrm{p}=0,011)$. Sementara itu, penderita stroke iskemik akut dengan riwayat DM terbukti mengalami peningkatan risiko luaran perawatan buruk sebesar 11,66 kali lebih tinggi dibandingkan dengan individu tanpa riwayat diabetes melitus $(R R=11,66$; IK95\% 2,00-67,65; $\mathrm{p}=0,006)$. Sedangkan riwayat dislipidemia terbukti meningkatkan risiko luaran perawatan buruk sebesar 11,45 kali lebih tinggi dibandingkan dengan individu tanpa dislipidemia (RR=11,45; IK95\% 1,10-119,23; $\mathrm{p}=0,041)$. Dengan demikian ketiga faktor tersebut merupakan prediktor independen terhadap luaran perawatan buruk pada penderita stroke iskemik akut secara konsisten.

Kekuatan penelitian ini adalah dikerjakan dengan metode kohort prospektif sehingga dapat diketahui faktor-faktor prediktor luaran buruk pada penderita stroke iskemik akut. Selain itu, pada penelitian ini dilakukan analisis multivariat sehingga faktor-faktor lain yang ikut berkontribusi terhadap luaran perawatan pada penderita stroke iskemik akut dapat dikendalikan. Sementara itu, kelemahan penelitian ini adalah tidak mengikutsertakan prediktor luaran perawatan lainnya seperti luas infark dan lokasi lesi karena keterbatasan pemeriksaan penunjang.

\section{KESIMPULAN}

Berdasarkan hasil penelitian ini, didapatkan mikroalbuminuria, diabetes melitus, dan dislipidemia berpengaruh terhadap luaran buruk selama perawatan pada penderita stroke iskemik akut. Diperlukan penelitian lebih lanjut berskala lebih besar untuk mengonfirmasi temuan tersebut.

\section{DAFTAR PUSTAKA}

1. Ghoshal S, Freedman BI. Mechanisms of Stroke in Patients with Chronic Kidney Disease. Am J Nephrol. 2019;50:229-39.

2. Kelly DM, Rothwell PM. Prevention and treatment of stroke in patients with chronic kidney disease: an overview of evidence and current guidelines. Kidney Int. 2020;97:266-78.

3. Hernandez-Diaz ZM, Pena-Sanchez M, GonzalezQuevedo Monteagudo A, dkk. Cerebral Small Vessel Disease Associated with Subclinical Vascular Damage Indicators in Asymptomatic Hypertensive Patients. Behav Sci (Basel) 2019;9. 
4. Pattanaik S, Dash P. Microalbuminuria in Patients with Recent Ischaemic Cerebrovascular Stroke: A Cross Sectional Study. Br J Med Med Res. 2016;14:1-9.

5. Weir MR. Microalbuminuria and cardiovascular disease. Clin J Am Soc Nephrol. 2007;2:581-90.

6. Lyden P. Using the National Institutes of Health Stroke Scale. Stroke. 2017;48:513-9.

7. Abbott AL, Silvestrini M, Topakian R, dkk. Optimizing the Definitions of Stroke, Transient Ischemic Attack, and Infarction for Research and Application in Clinical Practice. Front Neurol. 2017;8:537.

8. Thampy A, Pais CC. Early Clinical Implications of Microalbuminuria in Patients with Acute Ischaemic Stroke. J Clin Diagn Res. 2016;10:OC29-OC31.

9. Gumbinger C, Sykora M, Diedler J, Ringleb P, Rocco A. Microalbuminuria: A potential prognostic marker for acute stroke. Der Nervenarzt. 2012;83:1357-60.

10. Cha JK, Lim JH, Kim DH, dkk. Prognostic factors for long-term poor outcomes after acute ischemic stroke in very old age ( $>80$ years) patients: Total cholesterol level might differently influence long-term outcomes after acute ischemic stroke at ages above 80 years. Geriatr Gerontol Int. 2015;15:1227-33.

11. Louis RC. Caplan's Stroke: A Clinical Approach 5th Ed. New York: Cambridge University Press; 2016.

12. Gumbinger C, Sykora M, Diedler J, Ringleb P, Rocco A. Microalbuminuria: a potential prognostic marker for acute stroke. Nervenarzt. 2012;83:1357-60.
13. Zakria M, Sarfraz M, Ahmad T. Microalbuminuria among patients with acute ischemic stroke admitted in tertiary care hospital. TPMJ. 2017;24:6.

14. Roquer J, Segura T, Serena J, Castillo J. Endothelial dysfunction, vascular disease and stroke: the ARTICO study. Cerebrovascular Dis. 2009;27 Suppl 1:25-37.

15. Cuadrado-Godia E, Ois A, Garcia-Ramallo E, dkk Biomarkers to predict clinical progression in small vessel disease strokes: Prognostic role of albuminuria and oxidized LDL cholesterol. Atherosclerosis. 2011;219:368-72.

16. Lau LH, Lew J, Borschmann K, Thijs V, Ekinci EI. Prevalence of diabetes and its effects on stroke outcomes: A meta-analysis and literature review. J Diabetes Investig. 2019;10:780-92.

17. Chen R, Ovbiagele B, Feng W. Diabetes and Stroke: Epidemiology, Pathophysiology, Pharmaceuticals and Outcomes. Am J Med Sci. 2016;351:380-6.

18. Xu T, Zhang JT, Yang M, dkk. Dyslipidemia and outcome in patients with acute ischemic stroke. Biomed Environ Sci. 2014;27:106-10.

19. Manabe Y, Morihara R, Matsuzono K, dkk. Estimation of the Presence of Small Dense Lipoprotein Cholesterol in Acute Ischemic Stroke. Neurol Int. 2015;7:5973.

20. Pan B, Jin X, Jun L, Qiu S, Zheng Q, Pan M. The relationship between smoking and stroke: A metaanalysis. Medicine 2019;98:e14872. 